\title{
Seed vigor and germination of facheiro plants (Pilosocereus catingicola (Gurke) Byles \& Rowley Subsp. salvadorensis (Werderm.) Zappi (Cactaceae) at different temperatures
}

\section{Vigor e germinação de sementes de facheiro (Pilosocereus catingicola (Gürke) Byles \& Rowley subsp. salvadorensis (Werderm.) Zappi (Cactaceae) em diferentes temperaturas}

\author{
Robson Luis Silva de Medeiros ${ }^{1 *}$; Vênia Camelo de Souza ${ }^{2}$; \\ Gilvaneide Alves de Azerêdo ${ }^{3}$; Miguel Avelino Barbosa Neto ${ }^{4}$; \\ Alex da Silva Barbosa ${ }^{3}$; Ivan Sergio da Silva Oliveira ${ }^{5}$
}

\begin{abstract}
Several species of endemic Cactaceae are found in northeastern Brazil, which are important plants to the local fauna and flora; nevertheless, there are only a few studies assessing the germination of this plant genus. Understanding the germination of species native to the Caatinga is essential to subsidize conservation actions for such ecosystem. The objective of this study was to investigate the influence of three localities and different temperatures on the vigor and germination of facheiro seeds. The experiment was conducted by evaluating seed vigor and germination in three distinct areas (Arara, Bananeiras, and Boa Vista) at different temperatures $\left(20,25,30,35,40\right.$, and $\left.20-30^{\circ} \mathrm{C}\right)$. Quantitative data were submitted to polynomial regression analysis at $5 \%$ significance with four replicates of 50 seeds. In Arara, germination rates at 20 and $25{ }^{\circ} \mathrm{C}$ reached $96 \%$ and, at $30{ }^{\circ} \mathrm{C}, 86 \%$. The temperatures of 25 and $30^{\circ} \mathrm{C}$ presented the best germination speed index. For the three studied areas, the highest germination rates were recorded at a constant temperature of $25^{\circ} \mathrm{C}$ and at the alternating temperature $\left(20-30{ }^{\circ} \mathrm{C}\right)$. Yet the highest germination speed was reached at $30^{\circ} \mathrm{C}$. Based on its sexual propagation, the taxon in question is able to survive in environments with temperatures ranging from 20 to $30^{\circ} \mathrm{C}$, as seen in the studied habitats.
\end{abstract}

Key words: Agreste of Paraíba state. Facheiro. Physiological potential.

\section{Resumo}

No Nordeste brasileiro ocorrem diversas cactáceas endêmicas de grande importância para a fauna e flora, entretanto poucos são os estudos envolvendo germinação em cactáceas no Brasil, principalmente, no Nordeste. É de fundamental importância o conhecimento da germinação das espécies nativas da

\footnotetext{
1 Discente de Mestrado, Programa de Pós-Graduação em Agronomia, Produção Vegetal, Faculdade de Ciências Agrárias e Veterinárias, Universidade Estadual Paulista, FCAV/UNESP, Jaboticabal, SP, Brasil. E-mail: robsonluissm@hotmail.com

2 Prof ${ }^{a}$ Dra $^{\mathrm{a}}$, Departamento de Ciências Básicas e Sociais, Universidade Federal da Paraíba, CCHSA/UFPB, Campus de Bananeiras, Bananeiras, PB, Brasil. E-mail: venia_camelo@hotmail.com

3 Profs. Drs., Departamento de Agricultura, CCHSA/UFPB, Campus de Bananeiras, Bananeiras, PB, Brasil. E-mail: azeredogil@ yahoo.com.br; aldasibarbosa@gmail.com

4 Discente de Mestrado, Programa de Pós-Graduação em Agronomia, CCA/UFPB, Campus de Areia, Areia, Paraíba, Brasil. E-mail: miguelavelinoneto18@gmail.com

5 Discente de Bacharelado em Agroecologia, CCHSA/UFPB, Campus de Bananeiras, Bananeiras, PB, Brasil. E-mail: ivantecagro@ gmail.com

* Author for correspondence
} 
Caatinga, para subsidiar ações conservacionistas desses ecossistemas. O objetivo deste trabalho foi investigar a influência de diferentes localidades e temperaturas no vigor e germinação de sementes de facheiro. $\mathrm{O}$ experimento foi realizado, avaliando o vigor e a germinação de sementes das três áreas selecionadas (Arara, Bananeiras e Boa Vista) em diferentes temperaturas $\left(20^{\circ} \mathrm{C}, 25^{\circ} \mathrm{C}, 30^{\circ} \mathrm{C}, 35^{\circ} \mathrm{C}\right.$, $40^{\circ} \mathrm{C}$ e $20-30^{\circ} \mathrm{C}$ ). Os dados quantitativos foram submetidos à análise de regressão polinomial à $5 \%$ de significância, com quatro repetições de 50 sementes. Para a localidade de Arara-PB, a germinação nas temperaturas de 20 e $25{ }^{\circ} \mathrm{C}$ foi de $96 \%$, e na temperatura de $30{ }^{\circ} \mathrm{C}$, a germinação foi de $86 \%$. As temperaturas de $25^{\circ} \mathrm{C}$ e $30^{\circ} \mathrm{C}$ apresentaram os melhores Índice de Velocidade de Germinação. A espécie apresentou nas três áreas de ocorrência, germinação elevada nas temperaturas constantes de 25 e alternada $20-30^{\circ} \mathrm{C}$. Os maiores índices de velocidade de germinação foram obtidos na temperatura de $30^{\circ} \mathrm{C}$. O táxon nos habitats estudados têm capacidade de sobrevivência em ambientes que apresentem variações de temperatura de 20 a $30^{\circ} \mathrm{C}$ quanto à sua propagação sexuada.

Palavras-chave: Agreste paraibano. Facheiro. Potencial fisiológico.

\section{Introduction}

Cacti are among the most iconic groups of plants because they are adapted to drought conditions, and they are evolved and diversified under ecosystems of xeric conditions (MENEZES et al., 2016). The semiarid Caatinga and the seasonal Cerrado are among most important areas with cacti diversity in east Brazil, bringing together a significant amount of endangered species of the Cactaceae family (GOETTSCH et al., 2015).

The region contains several endemic Cactaceae species important to the regional fauna and flora. Among them are the mandacaru (Cereus jamacaru P. DC.), facheiro (Pilosocereus pachycladus Ritter), xiquexique [Pilosocereus gounellei (A. Weber ex K. Schum.) Bly ex Rowl], and coroa-de-frade (Melocactus bahiensis Britton \& Rose), which are mainly used for animal feed during the dry season in the region (BRITO CAVALCANTI et al., 2007). Pilosocereus Byles \& Rowley is one of the most representative genera of the Cactaceae family from the Brazilian flora, containing 29 species -26 are endemic - of the semiarid region (HUNT et al., 2006; ZAPPI et al., 2015).

The Caatinga has undergone several threats over the years, decreasing the natural populations and putting some Cactaceae species at risk of extinction (SILVA et al., 2011). The author also reports that the main threats for cacti are related to habitat fragmentation, mainly because of deforestation, agricultural development, and many other types of environmental disturbances, such as the human transit, urban sprawl, animal trampling, and Poaceae invasion of areas. In addition to these factors, large quantities of seeds and plants are illegally collected to supply the horticulture and ornamental markets, and rocky outcrops are destroyed through mining.

Germination performance of the native species from Caatinga is fundamental to subsidize actions to conserve these ecosystems. Therefore, determining suitable technologies to enable the use of seeds from native cactus species that develop in these regions constitute important tools for the implementation of afforestation and reforestation programs in Northeastern Brazil. Germination and viability studies of native Cactaceae seeds are scarce in the Northeast, and few results can be found in the scientific literature (ABUD et al., 2012).

Cactaceae species are propagated by two methods: sexual or asexual. The sexual propagation is not widely used due to the lack of information about this method. In sexual propagation, seedlings grow slowly, but they can be produced in great quantity. The seeds provide genetic variations and several desirable morphological characteristics (ABUD et al., 2010).

In many cases, the germination test is insufficient to evaluate the physiological quality of seeds; using 
other evaluation methods are necessary, such as vigor tests (VALADARES; PAULA, 2008), average germination time, and germination speed.

The rules for seed testing provide no information about the species; however, knowledge about the optimal conditions for germination is fundamental, especially temperature, because these factors vary according to the seeds and species (GUEDES et al., 2009).

Temperature affects the germination rate; the optimum temperature provides a maximum percentage of germination in a shorter period, while maximum or minimum temperatures result in small germination rates or even death of the embryo (CARVALHO; NAKAGAWA, 2012).

The genus Pilosocereus, as well as other species of this family, contributes to the sustainability of the Caatinga biome (CORREIA et al., 2011). The facheiro and other species of the genus, such as Pilosocereus gounellei (F.A.C. Weber) Byles \& Rowley subsp. gounellei (xiquexique), present economic importance to the region.
Therefore, knowing the eco-physiological aspects of the germination of facheiro seeds from different locations help in understanding the establishment of the seeds at different temperatures. The objective of this study was to evaluate the germination and vigor of Pilosocereus catingicola (Gürke) Byles \& Rowley Subsp. Salvadorensis (Werderm.) Zappi (Cactaceae) at different temperatures.

\section{Material and Methods}

Seeds used in the experiment were extracted from fresh ripe fruits in December 2014. They were harvested from natural populations of cacti from the municipalities of Arara (25 M 1920079243179 UTM), Bananeiras (25 M 203813.089259923 .81 UTM), and Boa Vista (24 M 6989819133272 UTM), all located in the State of Paraíba, Brazil. The forest fragments of the Caatinga sampled are located in the Agreste mesoregion of the Paraíba state (Figure 1).

Figure 1. Geographical scope of $P$. catingicola subsp. salvadorensis, and location of the studied municipalities in the Agreste region of the Paraíba state, Brazil.

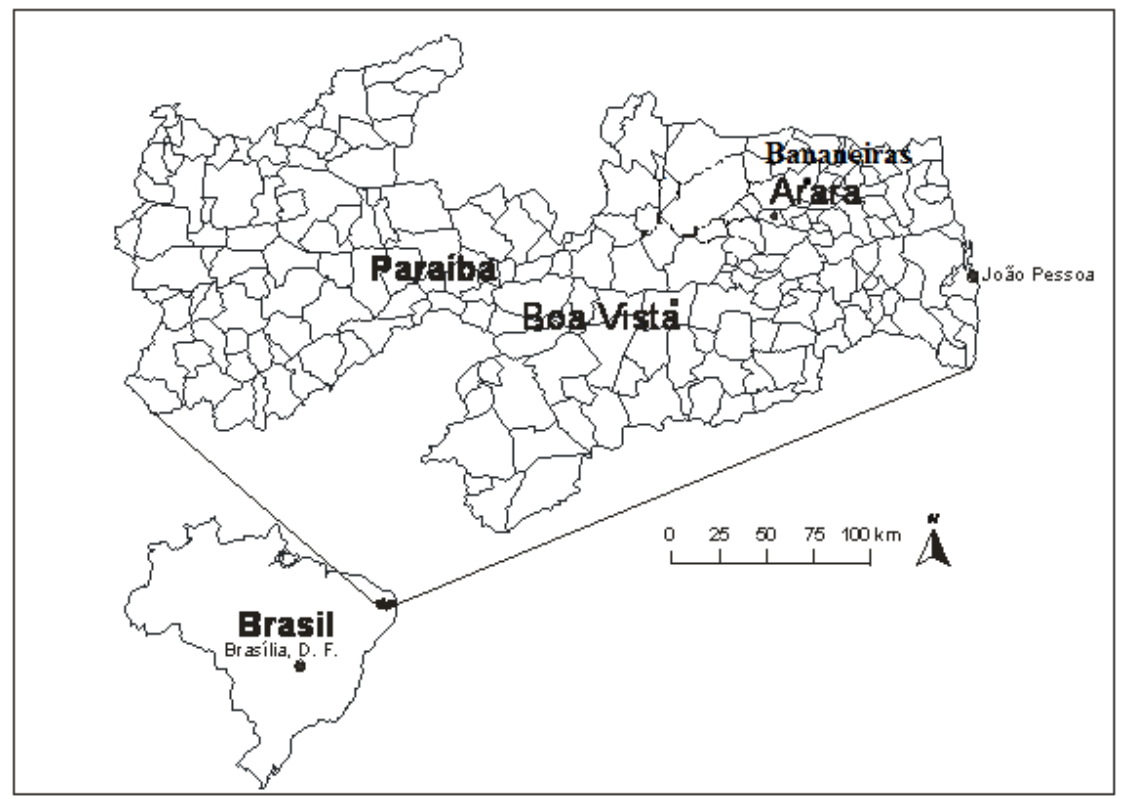


The three areas were chosen based on the high density of $P$. catingicola subsp. salvadorensis along the landscape; each one is distinct in terms of use and conservation. The three study areas are private properties.

The area in Arara is located in the Agreste mesoregion of the Paraíba state in the Borborema Plateau formed by massifs and high hillock, with the presence of Neosols, with variable fertility between medium and high (CPRM, 2005a). The climate is tropical and rainy with a dry summer and an average rainfall of $666.13 \mathrm{~mm}$ year $^{-1}$. The Caatinga is in the process of secondary succession, with constant woodcutting; the cattle and goats grazing during the dry season also affect the area (BARBOSA, 2015).

The municipality of Bananeiras is located in the Agreste mesoregion of the Paraíba state at an altitude ranging from 650 to 1,000 meters. Local soils are Neosols with an average natural fertility and deep Podzolics with clayey texture and mean to high natural fertility. The area has a rainy tropical climate with dry summers, and the rainy season from January/ February to September/October (CPRM, 2005b). The Caatinga is in the process of intermediate succession; in this biome, cattle, equines, and goats are used graze during the dry season, what affects the area.

The area in Boa Vista has an average to high fertility and a rainy tropical climate and hot dry summer. Boa Vista is covered by Caatinga plant formations where the plant species pass through deciduous in the dry season. The average annual rainfall is $443.93 \mathrm{~mm}$ year $^{-1}$, characterizing as the most xeric Caatinga among the areas of $P$. catingicola subsp. salvadorensis. The soil surface is smoothly undulated with medium-deep Planosols formations with average fertility. In addition, the soil surface is well drained with moderate acidity. Deep clayish Podzolics with average natural fertility are also found. Poorly drained Planosols and rock outcrops along the landscape compound this area (CPRM, 2005c). The Caatinga in Boa Vista is considered one of the most conserved areas, but more recently, the entry of goatherds was verified for controlled grazing during the dry season (BARBOSA, 2015).

Figure 2. Average, maximum, and minimum monthly rainfall and temperature of the municipalities of Arara (a), Bananeiras (b), and Boa Vista (c).
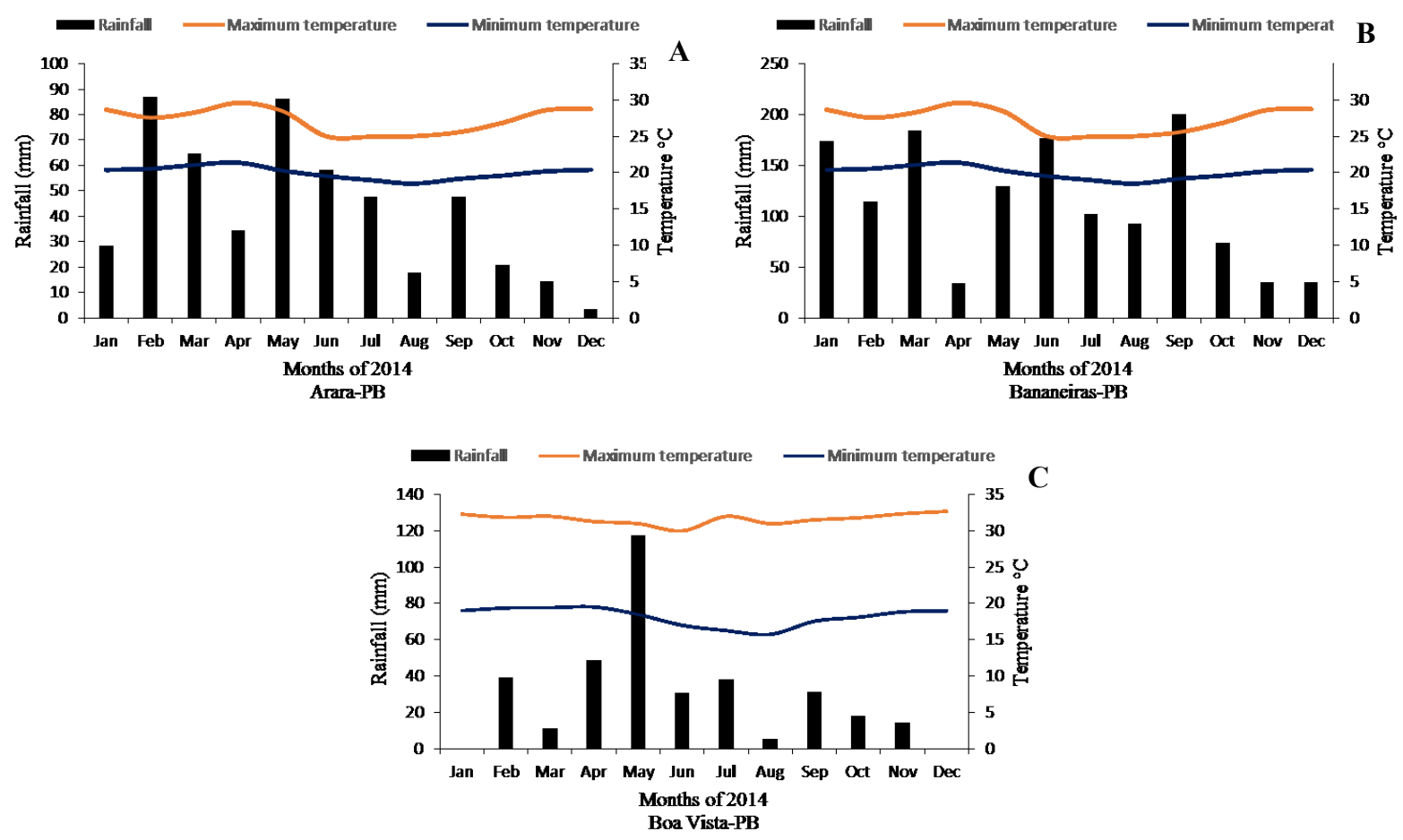
Rainfall data were acquired from the Executive Agency for Water Management in the state of Paraíba during the year of 2014 (AESA, 2017), and the maximum and minimum average temperatures (Figure 2) were acquired by consulting the Meteorological Database from the Nacional Institute of Meteorology (INMET, 2017).

\section{Biometry of the fruit}

After harvesting the fruits in the three sample areas, they were packed in paper bags and transported to the Laboratory of Seed Technology of the Centre for Human, Social, and Agrarian Sciences of the Federal University of Paraíba. Biometric measurements for length, diameter, and fruit weight were performed with the aid of a digital caliper with a resolution of $0.01 \mathrm{~mm}$ and an analytical scale with 0.01 decimal places. The length of the fruit was measured from the base and the apex of the fruit and the diameter was measured in the middle of the fruit. The fruits were pulped in a sieve and washed under running water to extract the seeds. Then, the seeds were dried in the shade for two days under lab conditions at $25^{\circ} \mathrm{C}$.

Germination: The test was conducted in germination boxes (Gerbox), using a germination paper test (Germitest) as the substrate, with two paper sheets on the bottom of the Gerbox. The seeds were placed on top of the paper and covered with another leaf. There were four replications of 50 seeds total. The substrate was moistened with distilled water 2.5 times the mass of the non-hydrated paper (BRASIL, 2009). The seeds were placed in germinators regulated at constant temperatures of 20, 25, 30, $35,40{ }^{\circ} \mathrm{C}$, and one germinator at an alternating set of $20-30{ }^{\circ} \mathrm{C}$, with 12 hours of photoperiod for each temperature. Seeds with the radicle emerging were considered germinated. The seedlings were counted until the 30th day after sowing when they stabilized.

Vigor: This variable was indirectly quantified by the average time of germination in days, quantifying the germination from the kinetic viewpoint, $\mathrm{t}=\Sigma$ ni.
ti/Sni (LABOURIAU; AGUDO, 1987) and by the germination speed index $(\mathrm{GSI}=\mathrm{G} 1 / \mathrm{N} 1+\mathrm{G} 2 / \mathrm{N} 2+\ldots$ $\mathrm{Gn} / \mathrm{Nn}$ ) (MAGUIRE, 1962). According to the tests of normality and homogeneity of variances, we did not need to transform the data of GSI (OLIVEIRA et al., 2015).

Statistical analysis of the data was performed using a completely randomized experimental design with four replicates of 50 seeds and treatments distributed in a factorial scheme $3 \times 6$ ( 3 localities and 6 temperatures). The data were submitted to ANOVA. Polynomial regression was performed for the constant temperatures in the studied locations.

\section{Results and Discussion}

Table 1 shows the biometric data of the fruit. The fruit from the municipality of Bananeiras presented larger weight, length, and width, which can be connected to the high precipitation of Bananeiras, (Figure 2). Abud et al. (2010), studying fruit of Pilosocereus pachycladus F. Ritter, observed fruit with the width of $50.53 \pm 5.01$ and a length of 38.13 \pm 4.52. The fruit widths from Arara, Bananeiras, and Boa Vista were smaller than those studied by Abud et al. (2010), featuring larger standard deviations. The fruit from Boa Vista presented the lowest standard deviations for all variables. The fruit from the Arara locality showed an average weight of $34.33 \pm 16.28$, Boa Vista $35.03 \pm 5.77$, and Bananeiras $55.28 \pm 13.99$.

The differences found among the facheiro fruit may be related to the variation of each environment, the use of nutrients, water resources available. In addition, the genotypic diversity of the populations can also result in different phenotypic characteristics for the species (ISMAEL, 2009; SILVA et al., 2012). Figure 2 shows a direct relationship between the rainfall rate and the size of the fruit in the municipality of Bananeiras. The city receiving more rainfall presented larger fruit than the other localities. When studying the phenology of chiropterophilous and sphingophilous species in the 
Caatinga, Lucena (2007) showed that the specimens of the genus Pilosocereus occurred regularly during the study period, presenting reproductive structures, such as flowers and fruits, throughout the year with a higher intensity at the beginning of the rainy season. Another observationwas the manifestation of this interspecific synchronous phenophases during the peaks (BARBOSA, 2015).

Table 1. Facheiro fruit biometric collected in areas of Caatinga in the municipalities of Arara, Bananeiras, and Boa Vista, Westland of Paraíba State in Northeastern Brazil.

\begin{tabular}{cccc}
\hline Characteristics & Arara & Bananeiras & Boa Vista \\
\hline Width $(\mathbf{m m})$ & $44.37 \pm 11.38$ & $47.84 \pm 7.10$ & $43.43 \pm 4.74$ \\
Length $(\mathbf{m m})$ & $34.30 \pm 6.69$ & $42.41 \pm 5.08$ & $33.66 \pm 2.75$ \\
Weight $\mathbf{( g )}$ & $34.33 \pm 16.28$ & $55.28 \pm 13.99$ & $35.03 \pm 5.77$ \\
\hline
\end{tabular}

The differences found among the facheiro fruit may be related to the variation of each environment, the use of nutrients, water resources available. In addition, the genotypic diversity of the populations can also result in different phenotypic characteristics for the species (ISMAEL, 2009; SILVA et al., 2012). Figure 2 shows a direct relationship between the rainfall rate and the size of the fruit in the municipality of Bananeiras. The city receiving more rainfall presented larger fruit than the other localities. When studying the phenology of chiropterophilous and sphingophilous species in the Caatinga, Lucena (2007) showed that the specimens of the genus Pilosocereus occurred regularly during the study period, presenting reproductive structures, such as flowers and fruits, throughout the year with a higher intensity at the beginning of the rainy season. Another observation was the manifestation of this interspecific synchronous phenophases during the peaks (BARBOSA, 2015).

Table 2 shows the analysis of the variance of the germination and speed of germination seed index for different locations tested at different temperatures. The location and temperature, isolated factors, and the interaction of these factors was significant to this study.

Regarding the effect of temperature on seed germination, one can note that rates were higher in the temperatures of $20-30,25$, and $30^{\circ} \mathrm{C}$, regardless of the locality. In the studied areas, the facheiro seeds support a temperature variation because the temperature of $20-30{ }^{\circ} \mathrm{C}$ was favorable for the germination of seeds, showing a germination of $80 \%$. The temperatures of 20 (except in Arara), 35 , and $40{ }^{\circ} \mathrm{C}$ were detrimental to the germination process of facheiro, but the alternating temperature was favorable in the three localities, which may infer that the seeds of this species are adapted to seek sharp changes in temperatures in their habitat. Rojas-Aréchiga and Vásquez-Yanes (2000) ensure that the optimal temperature for germination of cactaceous seeds is around $25^{\circ} \mathrm{C}$, as verified in this study. Guedes et al. (2009) found the temperature of $30{ }^{\circ} \mathrm{C}$ was more suitable for conducting tests of germination and vigor in Cereus jamacaru DC seeds.

Table 3 compares the temperatures within each locality; seeds coming from Arara have the highest germination rates at temperatures of 20 and $25{ }^{\circ} \mathrm{C}$. These treatments are similar statistically, followed by the temperature at $30^{\circ} \mathrm{C}$. The highest germination values were obtained at $25^{\circ} \mathrm{C}$ for seeds from Boa Vista, followed by temperatures of 20-30 and $30{ }^{\circ} \mathrm{C}$. The temperatures of 20,35 , and $40^{\circ} \mathrm{C}$, (except in Arara) were harmful to the germination process of facheiro seeds. However, the alternating temperature of $20-30{ }^{\circ} \mathrm{C}$ was favorable to the three localities; this shows that the seeds of this species 
are adapted to sudden temperature variations in their habitat. When evaluating the effect of the localities at each temperature, the seeds from Arara presented high germination at $20^{\circ} \mathrm{C}$, which differs statistically from the other localities. At temperatures of 25 and $30{ }^{\circ} \mathrm{C}$, there were no significant differences among the localities. At temperatures of 35 and $40{ }^{\circ} \mathrm{C}$, seeds from Bananeiras showed the highest speed of germination. In a study with the same taxon on substrate paper filter, Meiado et al. (2016), the temperature of $25^{\circ} \mathrm{C}$ with 12 hours of photoperiod germination was higher than $92 \%$ and at $30{ }^{\circ} \mathrm{C}$ was higher than $80 \%$.

Table 2. Variance analysis summary for the evaluated factors during germination and vigor tests on Pilosocereus catingicola seeds (Gurke) Byles \& Rowley subsp. salvadorensis (WERDERM.) Zappi (Cactaceae).

\begin{tabular}{|c|c|c|c|c|}
\hline \multirow{2}{*}{ Variation source } & \multirow{2}{*}{ DF } & MS & SS & $\mathrm{F}$ \\
\hline & & Germination & & \\
\hline Locality (L) & 2 & 782.7222 & 1565.4444 & $23.5078 * *$ \\
\hline Temperature (T) & 5 & 15017.6889 & 75088.4444 & $451.0318 * *$ \\
\hline $\mathrm{L} \times \mathrm{T}$ & 10 & 1212.6556 & 12126.5556 & $36.4201 * *$ \\
\hline Residue & 54 & 33.2963 & 1798.0000 & \\
\hline $\mathrm{CV}(\%)$ & 10.44 & & & \\
\hline \multirow{2}{*}{ Variation source } & \multirow{2}{*}{ DF } & MS & SS & $\mathrm{F}$ \\
\hline & & GSI & & \\
\hline Locality (L) & 2 & 62.7210 & 125.4419 & $19.3630 * *$ \\
\hline Temperature $(\mathrm{T})$ & 5 & 404.3651 & 2021.8257 & $124.8344^{* *}$ \\
\hline $\mathrm{L} \times \mathrm{T}$ & 10 & 80.8345 & 808.3447 & $24,9550^{* *}$ \\
\hline Residue & 54 & 3.2392 & 174.9175 & \\
\hline CV $(\%)$ & 20.40 & & & \\
\hline
\end{tabular}

$\mathrm{NS}, * \mathrm{e} * *=$ Não-significativo, significativo a 5 e $1 \%$ de probabilidade, respectivamente, pelo teste $\mathrm{F}$.

$\mathrm{NS}, *$, and $* *=$ non-significant, significant at $5 \%$, and significant at $1 \%$ probability, respectively by the $\mathrm{F}$ test.

Table 3. Germination rate (\%) and germination speed index (GSI) of Pilosocereus catingicola (Gurke) Byles \& Rowley subsp. salvadorensis (Werderm.) Zappi (Cactaceae) seeds in the municipalities of Arara, Bananeiras, and Boa Vista - PB, Brazil. Uppercase letters compare temperatures at each location, and lowercase letters compare localities in each temperature.

\begin{tabular}{cccccccc}
\hline & Temperatures & 20 & 25 & 30 & 35 & 40 & $20-30$ \\
\hline \multirow{3}{*}{ Germination } & Arara & $96 \mathrm{Aa}$ & $92.5 \mathrm{ABa}$ & $82 \mathrm{BCa}$ & $5.5 \mathrm{Db}$ & $11.5 \mathrm{Db}$ & $79 \mathrm{Ca}$ \\
& Bananeiras & $24.5 \mathrm{Cc}$ & $96 \mathrm{Aa}$ & $77 \mathrm{Ba}$ & $26 \mathrm{Ca}$ & $26 \mathrm{Ca}$ & $81 \mathrm{Ba}$ \\
& Boa Vista & $39.5 \mathrm{Cb}$ & $92.5 \mathrm{Aa}$ & $77 \mathrm{Ba}$ & $4 \mathrm{Db}$ & $4 \mathrm{Db}$ & $81 \mathrm{ABa}$ \\
\hline $\mathrm{CV}(\%)$ & 10.44 & & & & & & \\
\hline \multirow{2}{*}{$\mathrm{GSI}$} & Arara & $10.7 \mathrm{Ba}$ & $15.82 \mathrm{Aa}$ & $5.8 \mathrm{Cb}$ & $0.95 \mathrm{Db}$ & $1.4 \mathrm{Db}$ & $8.3 \mathrm{Bc}$ \\
& Bananeiras & $3.5 \mathrm{Db}$ & $11.35 \mathrm{Bb}$ & $16.27 \mathrm{Aa}$ & $7.425 \mathrm{Ca}$ & $5.1 \mathrm{CDa}$ & $18.7 \mathrm{Aa}$ \\
& Boa Vista & $2.6 \mathrm{Bb}$ & $15.4 \mathrm{Aa}$ & $16.37 \mathrm{Aa}$ & $0.6 \mathrm{Bb}$ & $0.625 \mathrm{Bb}$ & $17.9 \mathrm{Aa}$ \\
\hline $\mathrm{CV}(\%)$ & 20.40 & & & & & \\
\hline
\end{tabular}

According to Lone et al. (2014), the constant temperatures of 25 and $30{ }^{\circ} \mathrm{C}$ and the alternating temperatures of $20-30{ }^{\circ} \mathrm{C}$ were adequate for the germination of pitaya seeds (Cactaceae), Hylocereus undatus, and for the hybrid Hylocereus undatus $\mathrm{x}$
Hylocereus costaricensis. Corroborating also with Abud et al. (2010), the facheiro seeds behaved as positively photoblastic at constant temperatures of 25 and $30^{\circ} \mathrm{C}$, providing the highest germination rates and GSI values. Marcos Filho (2015) stated that the 
effects of light on positively photoblastic seeds are beneficial and drive the synthesis of hormones and enzymes, respiratory control, tegument permeability to oxygen, and lipid metabolism.

Table 3 shows that the GSI of seeds arising from Arara presented the highest vigor at $25{ }^{\circ} \mathrm{C}$ (16.0), while for those from Bananeiras and Boa Vista the temperature was $30^{\circ} \mathrm{C}(16.27)$. When comparing the localities within each temperature, depending on the temperature used, one or more localities stand out. We could not state with certainty which location stood out in terms of producing seeds with greater vigor. At $30^{\circ} \mathrm{C}$ and at the alternating temperature 20-30 ${ }^{\circ} \mathrm{C}$, Bananeiras and Boa Vista stood out, while at $25^{\circ} \mathrm{C}$, Arara did.

The highest germination rates were obtained at temperatures of 25 and $30{ }^{\circ} \mathrm{C}$ (constant). The largest decrease was observed when the seeds were subjected to the highest temperatures, 35 and $40{ }^{\circ} \mathrm{C}$, regardless of the locality. Abud et al. (2012) claim that studies related to germination and viability of Cactaceae seeds native from the Northeast region are still scarce, and there are few in scientific literature. Seeds from different species present variable germinative behavior according to the temperature, which may provide information on biological and ecological interest (LABOURIAU, 1983).

Figure 3 shows the facheiro seeds' germination behavior from Arara. The data are fit to the quadratic polynomial regression model. The germination decreases with increasing temperatures. From $30^{\circ} \mathrm{C}$ on, a drastic fall occurs in the highest temperatures of 35 and $40{ }^{\circ} \mathrm{C}$. The germination rates were $96 \%$, $92.5 \%$, and $82 \%$ at temperatures of 20,25 , and $30{ }^{\circ} \mathrm{C}$, respectively, decreasing sharply at higher temperatures.

Figure 3. Germination rate of facheiro seeds from a natural population located in Arara, PB.

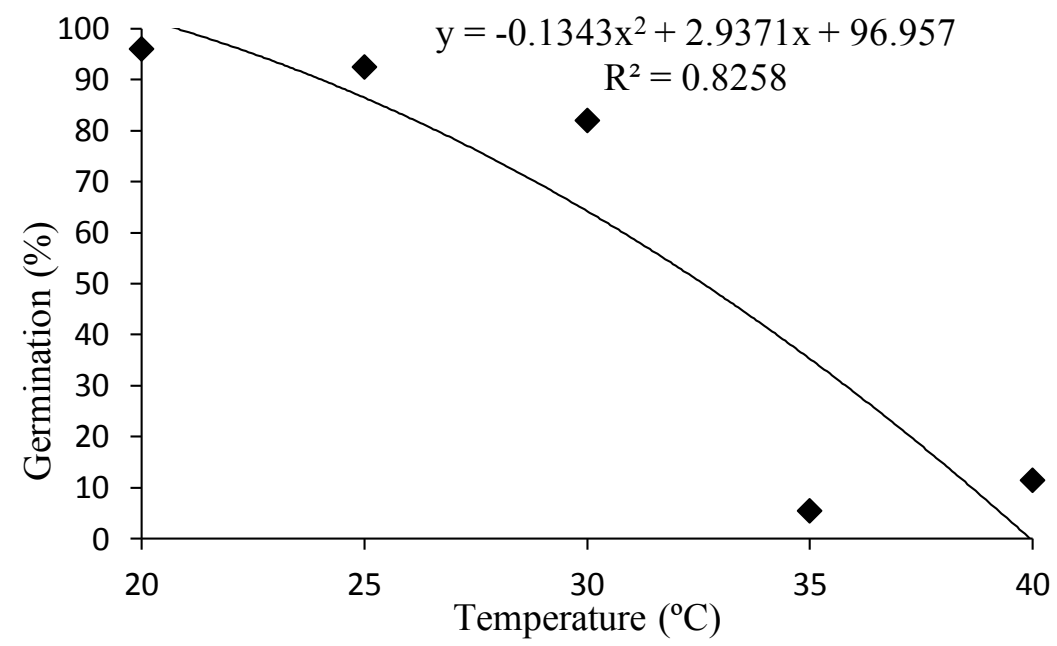

Temperature is an important factor able to restrict the occurrence of many species in certain ecosystems, preventing germination and establishment of the seedling under unfavorable conditions. Studies on the influence of temperature on seed germination are essential for the understanding of ecological and physiological aspects and the occurrence of species in natural environments (LABOURIAU, 1983; BEWLEY; BLACK, 1994).
Meiado et al. (2010) evaluated the germination of 30 taxa of Cactaceae collected in the Northeast region of Brazil. Among the temperatures tested by these authors, the alternating temperatures were less favorable for germination than were the constant ones. They also set as optimal for Cactaceae seed germination temperatures between 20 and $35^{\circ} \mathrm{C}$.

Favorable temperatures for cactus seeds are between 15 and $35^{\circ} \mathrm{C}$. For instance, Rojas-Aréchiga 
and Vásquez-Yanes (2000) concluded that the optimum temperature for germination of the seeds of Cactaceae was around $25^{\circ} \mathrm{C}$. GUEDES et al. (2009) found that the use of paper roll as substrate proved to be more suitable for conducting seed germination and vigor tests on Cereus jamacaru DC at a temperature of $30{ }^{\circ} \mathrm{C}$. Abud et al. (2013) evaluated different temperatures in seeds of Cereus jamacaru DC from the State of Ceará; the best temperature for the germination of this species was $25{ }^{\circ} \mathrm{C}$.

The germination rates of seeds from both Bananeiras and Boa Vista were adjusted to a quadratic polynomial regression model (Figures 4 and 5 ). At $20^{\circ} \mathrm{C}$, only $24 \%$ seeds germinated; at $25{ }^{\circ} \mathrm{C}$, it reached a maximum of $96 \%$; from 30 ${ }^{\circ} \mathrm{C}$ onwards, the rate decreased. These outcomes evidence a deleterious effect of temperatures such as 35 and $40^{\circ} \mathrm{C}$.

Figure 4. Germination rate of facheiro seeds from a natural population located in Bananeiras, PB.

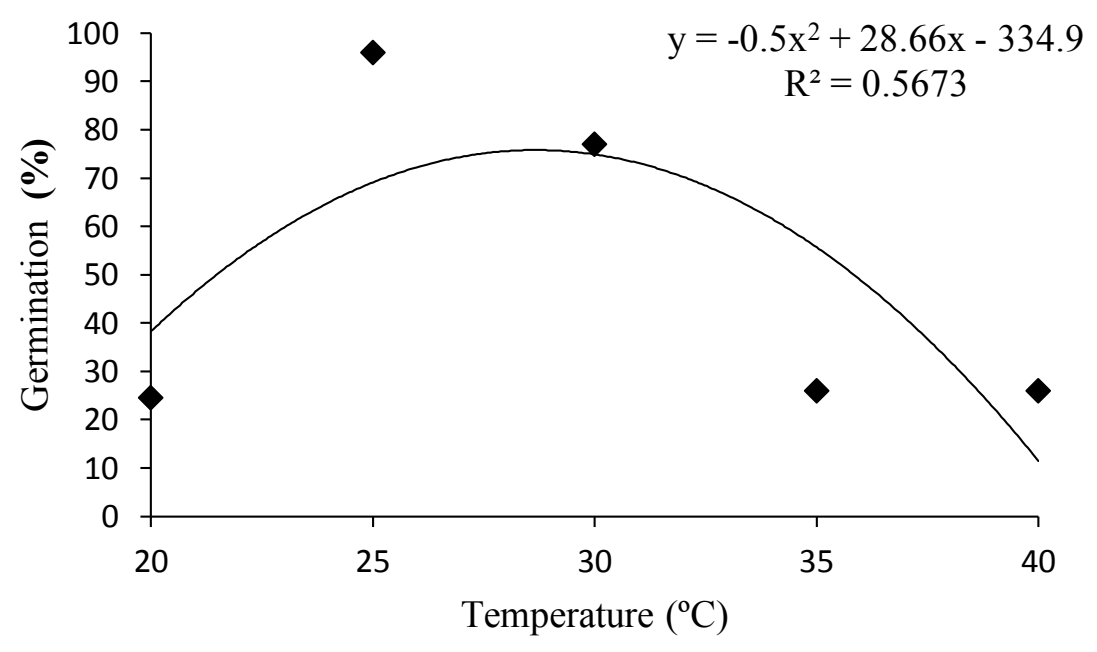

Figure 5. Germination rate of facheiro seeds from Boa Vista-PB and submitted to different temperatures. Bananeiras, PB, Brazil. 2015.

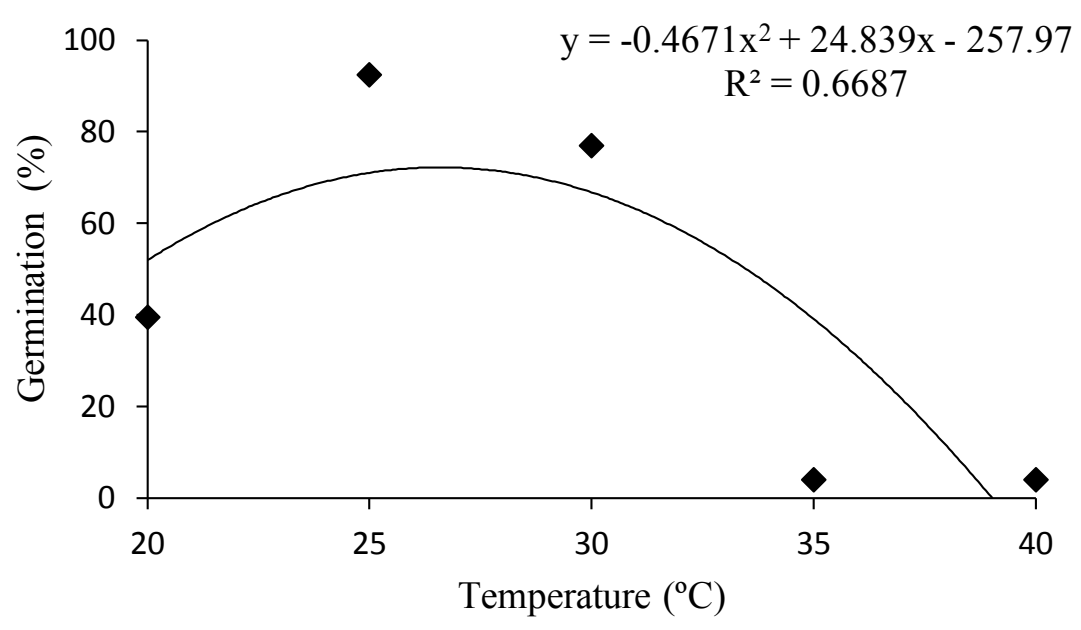


Figure 5 shows the facheiro seed germination from Boa Vista-PB. The data also adjusted to the quadratic polynomial regression model with the highest percentage $(92.5 \%)$ of germination at 25 ${ }^{\circ} \mathrm{C}$, decreasing sharply at the highest temperatures, reaching $4 \%$.

Guedes et al. (2009) studied the germination of Cereus jamacaru DC. subsp. jamacaru with seeds collected in the municipality of Boa Vista, State of Paraíba and obtained similar results with germination higher than $80 \%$ at temperatures of 25 and $30^{\circ} \mathrm{C}$.

Regarding the germination speed index (Figures 6, 7, and 8), the data from the three localities adjusted to the quadratic polynomial regression model. Analyzing the localities of Bananeiras and Boa Vista (Figures 7 and 8, respectively); there is a continuous increase in germination speed index from 20 to $30{ }^{\circ} \mathrm{C}$ when it reaches its maximum vigor. From this point, there is a sharp decrease in vigor for Boa Vista (Figure 8) at temperatures of 35 and $40^{\circ} \mathrm{C}$. For the location of Arara (Figure 6), the germination speed index was also increasing up to $30{ }^{\circ} \mathrm{C}$; however, the highest GSI was reached at $20{ }^{\circ} \mathrm{C}$; this effect was not observed in the other localities. The germination and vigor data, evaluated by the germination speed index, differ according to the locality and temperature tested. Minimum and maximum temperatures affect the germination process of germination of seeds.

Figure 6. Germination speed index (GSI) of facheiro seeds from a natural population located in Arara, PB, Brazil.

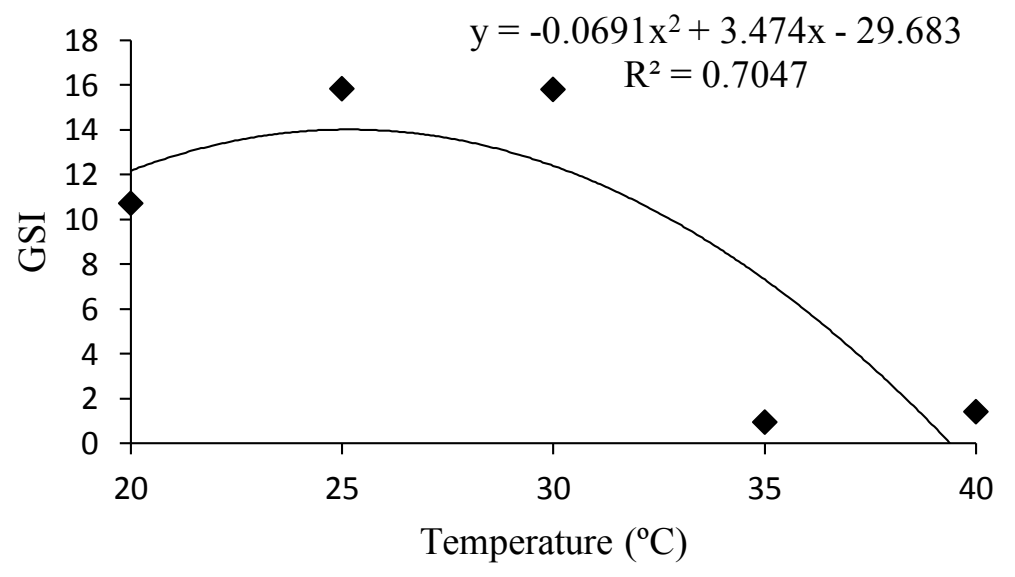


Figure 7. Germination speed index (GSI) of facheiro seeds from a natural population located in Bananeiras, PB, Brazil.

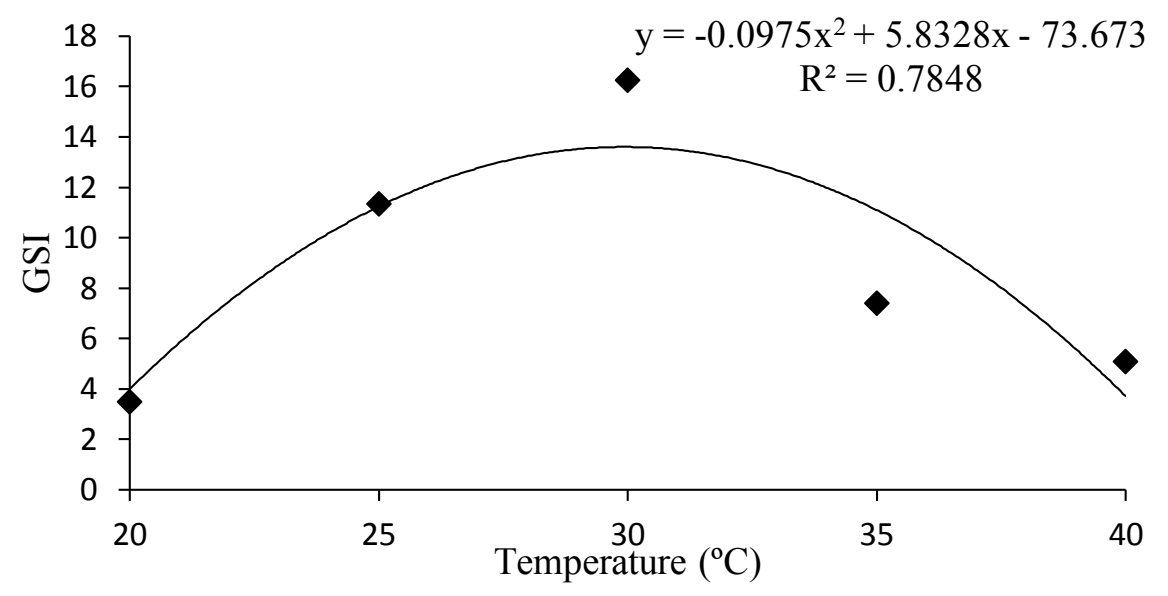

Figure 8. Germination speed index (GSI) of facheiro seeds from a natural population located in Boa Vista, PB, Brazil.

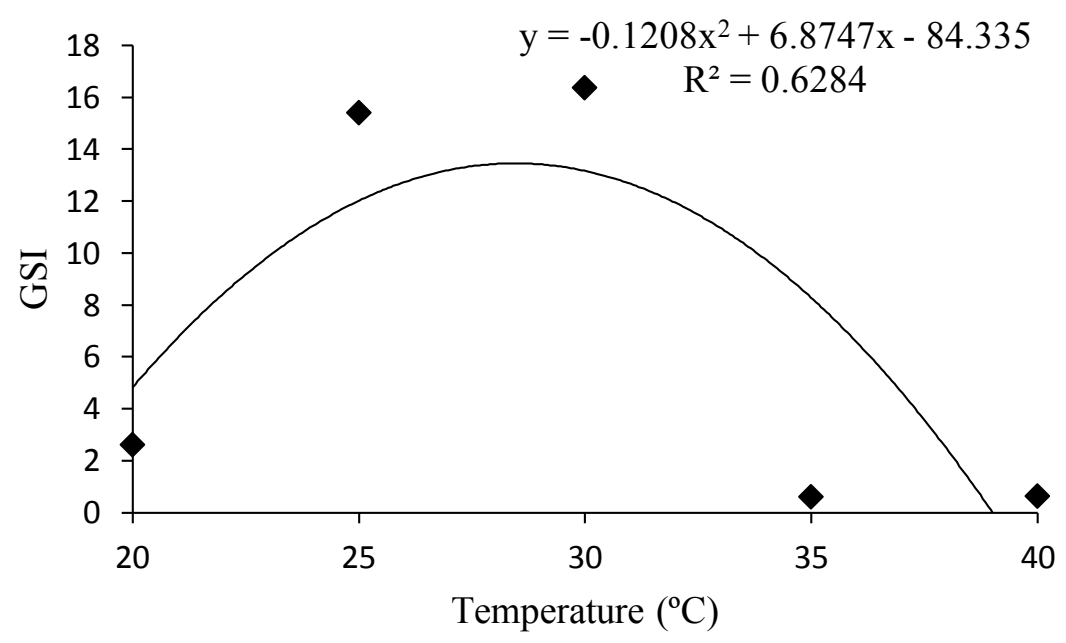

Baskin and Baskin (2001) mentioned that temperatures below or above the optimum range tend to reduce the germination speed, causing the seeds to be exposed for a longer period to adverse factors, which may lead to a reduction in total germination. This may explain the inferior performance obtained by the facheiro seeds when subjected to the high temperatures of 35 and $40{ }^{\circ} \mathrm{C}$, as well as the low temperature of $20{ }^{\circ} \mathrm{C}$ (except for the locality of Arara). Medeiros et al. (2015), who the same species with seeds from the municipalities Arara, Areial, and Boa Vista in the state of Paraíba, obtained a germination speed index of 7.1 with alternating temperatures of $20-30^{\circ} \mathrm{C}$ and a constant temperature of $30{ }^{\circ} \mathrm{C}$. Regarding the species Pilosocereus pachycladus, Abud et al. (2010) obtained a germination speed index of 7.0 at a temperature of $30{ }^{\circ} \mathrm{C}$ and 4.3 with a temperature of 20-30 ${ }^{\circ} \mathrm{C}$. According to these authors, the constant temperatures of 25 and $30{ }^{\circ} \mathrm{C}$ provided the highest percentages and speeds of germination of facheiro seeds. 


\section{Conclusion}

The species showed a high germination rate at constant temperatures of 25 and $30{ }^{\circ} \mathrm{C}$ and at an alternating temperature of $20-30{ }^{\circ} \mathrm{C}$ in the three studied areas. In general, the highest germination speed was obtained at temperatures of 25,30 , and 20-30 ${ }^{\circ} \mathrm{C}$.

For the studied localities, the taxon in question has the ability to survive in environments with temperatures ranging from 20 to $30^{\circ} \mathrm{C}$ regarding its sexual propagation.

\section{Acknowledgments}

We would like to thank the LATES; the Center for Human, Social, and Agrarian Sciences of the Federal University of Paraíba (UFPB); and the $\mathrm{CNPq}$ for the research funding.

\section{References}

ABUD, H. F.; GONÇALVES, N. R.; REIS, R. G. E.; PEREIRA, D. S.; BEZERRA, A. M. E. Germinação e expressão morfológica de frutos, sementes e plântulas de Pilosocereus pachycladus Ritter. Revista Ciência Agronômica, Fortaleza, v. 41, n. 3, p. 468-474, jul. 2010.

ABUD, H. F.; PEREIRA, D. S.; GONÇALVES, N. R.; PEREIRA, M. S.; BEZERRA, A. M. E. Armazenamento de sementes de xique-xique. Revista Brasileira de Sementes, Londrina, v. 34, n. 3, p. 473-479, jul. 2012.

Germination and morphology of fruits, seeds, and plants of Cereus jamacaru DC. Journal of Seed Science, Londrina, v. 35, n. 3, p. 310-315, jul. 2013.

AGÊNCIA EXECUTIVA DE GESTÃO DAS ÁGUAS DO ESTADO DA PARAIIBA - AESA. João Pessoa. Disponível em: <http://www.aesa.pb.gov.br/>. Acesso em: 20 maio 2017.

BANCO DE DADOS METEOROLÓGICOS PARA ENSINO E PESQUISA - BDMEP. Brasília. Disponível em: <http://www.inmet.gov.br/projetos/rede/pesquisa/>. Acesso em: 29 maio 2017.

BARBOSA, A. S. Ecologia populacional, características anatômica e perfil metabolômico de [Pilosocereus pachycladus F. Ritter (Cactaceae)]. 2015. Tese (Doutorado em Agronomia) - Universidade Federal da Paraíba, Areia.
BASKIN, C. C.; BASKIN, J. M. Seeds: ecology, biogeography, and evolution of dormancy and germination. San Diego: Academic Press, 2001. 666 p.

BEWLEY, J. D.; BLACK, M. Seeds: physiology of development and germination. $2^{\text {th }}$ ed. New York: Plenum Press, 1994. 445 p.

BRASIL. Ministério da Agricultura e Reforma Agrária. Regras para análises de sementes. Brasília: SNDA/ DNDV/CLAV, 2009. 399 p.

BRITO CAVALCANTI, N.; MILANEZ DE RESENDE, G. Efeito de diferentes substratos no desenvolvimento de Mandacaru (Cereus jamacaru P. DC.), Facheiro (Pilosocereus pachycladus RITTER), Xiquexique (Pilosocereus gounellei (A. WEBWR EX K. SCHUM.) BLY. EX ROWL.) E Coroa-de-frade (Melocactus bahiensis BRITTON \& ROSE). Revista Caatinga, Mossoró, v. 20, n. 1, p. 28-35, jan. 2007.

GUEDES, R. S.; ALVES, E. U.; GONÇALVES, E. P.; BRUNO, R. L. A.; BRAGA JÚNIOR, J. M.; MEDEIROS, M. S. Germinação de sementes de Cereus jamacaru DC. em diferentes substratos e temperaturas. Acta Scientiarum. Biological Sciences, Maringá, v. 31, n. 2, p. 159-164, 2009.

HUNT, D. R.; TAYLOR, N. P.; CHARLES, G. New cactus lexicon. Milborne Port. dh books, 2006. 899 p.

ISMAEL, J. C. B. Caracterização física de frutos e sementes, morfologia da plântula e secagem de sementes de cumaru [Dipteryx odorata (Aubl.) Willd]. 2009. Dissertação (Mestrado em Botânica) - Universidade Federal Rural da Amazônia, Bélem.

LABOURIAU, L. G. A germinação das sementes. Washington: Secretaria Geral da Organização dos Estados Americanos, 1983. 174p.

LABOURIAU, L. G.; AGUDO, M. On the physiology of seed-germination in salvia-hispanica 1. 1. Temperature effects. Anais da Academia Brasileira de Ciências, Rio de Janeiro v. 59, n. 1-2, p. 37-56, 1987.

LONE, A. B.; COOMBO, R. C.; FAVETTA, V.; TAKAHASHI, L. S. A.; FARIA, R. T. Temperatura na germinação de sementes de genótipos de pitaya. Semina: Ciências Agrárias, Londrina, v. 35, n. 4, p. 2251-2258, 2014.

LUCENA, E. A. R. M. Fenologia, biologia da polinização e da reprodução de Pilosocereus Byles \& Rowley (Cactaceae) no nordeste do Brasil. 2007. Tese (Doutorado em Biologia Vegetal) - Universidade Federal de Pernambuco, Recife. 
MAGUIRE, J. D. Speed of germination-aid in selection and evaluation for seedling emergence and vigor. Crop Science, Madison, v. 2, n. 1, p. 176-177, 1962.

MARCOS FILHO, J. Fisiologia de sementes de plantas cultivadas. 2. ed. Londrina: ABRATES, 2015. 660 p.

MEDEIROS, R. L. S.; SOUZA, V. C.; AZEREDO, G. A. de.; PEREIRA, E. M.; BARBOSA NETO, M. A.; MEDEIROS, V. S.; BARBOSA, A. S. Germinação e vigor de sementes de Pilosocereus catingicola (Gürke) Byles \& Rowley subsp. salvadorensis (Werderm.) Zappi (Cactaceae) da Caatinga Paraibana. Gaia Scientia, João Pessoa, v. 9, n. 2, p. 61-66, 2015.

MEIADO, M. V.; ALBUQUERQUE, L. S. C.; ROCHA, E. A.; ROJAS-ARÉCHIGA, M.; LEAL, I. R. Seed germination responses of Cereus jamacaru DC. ssp. jamacaru (Cactaceae) to environmental factors. Plant Species Biology, Kyoto, v. 25, n. 2, p. 120-128, 2010.

MEIADO, M. V.; ROJAS $\square$ ARÉCHIGA, M.; SIQUEIRA $\square$ FILHO, J. A.; LEAL, I. R. Effects of light and temperature on seed germination of cacti of Brazilian ecosystems. Plant Species Biology, Kyoto, v. 31, n. 2, p. 87-97, 2016.

OLIVEIRA, A. K. M.; SOUZA, J. S.; CARVALHO, J. M. B.; SOUZA, S. A. Germinação de sementes de paude-espeto (Casearia gossypiosperma) em diferentes temperaturas. Floresta, Curitiba, v. 45, n. 1, p. 97-106, 2015.

ROJAS-ARÉCHIGA, M.; VÁSQUEZ-YANES, C. Cactus seed germination: a review. Journal of Arid Environments, London, v. 44, n. 1. p. 85-104, 2000.

SERVIÇO GEOLÓGICO DO BRASIL - CPRM. Serviço Geológico do Brasil Projeto cadastro de fontes de abastecimento por água subterrânea. Diagnóstico do município de Arara, estado da Paraíba. In: BELTRÃO, B. A.; MORAIS, F.; MASCARENHAS, J. C.; MIRANDA, J. L. F.; SOUZA JUNIOR, L. C.; MENDES, V. A. (Org.). Recife: CPRM/PRODEEM, 2005a. p. 20. Disponível em: $\quad<$ http://rigeo.cprm.gov.br/xmlui/bitstream/handle/ doc/15797/Rel_Arara.pdf? sequence=1>. Acesso em: 20 jun. 2016.
Diagnóstico do município de

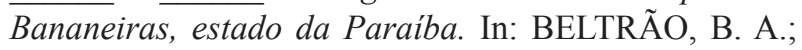
MORAIS, F.; MASCARENHAS, J. C.; MIRANDA, J. L. F.; SOUZA JUNIOR, L. C.; MENDES, V. A. (Org.). Recife: CPRM/PRODEEM. 2005b. p. $11+$ anexos. Disponível em: <http://rigeo.cprm.gov.br/ xmlui/bitstream/handle/doc/15814/Rel_Bananeiras. pdf?sequence $=1>$. Acesso em: 20 jun. $201 \overline{6}$.

. Diagnóstico do município de Boa Vista,

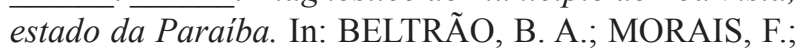
MASCARENHAS, J. C.; MIRANDA, J. L. F.; SOUZA JUNIOR, L. C.; MENDES, V. A. (Org.). Recife: CPRM/ PRODEEM. 2005c. p. 11. Disponível em: http://rigeo. cprm.gov.br/xmlui/bitstream/handle/doc/15807/Rel_ Boa_Vista.pdf? sequence=1>. Acesso em: 20 jun. 2016.

SILVA, J. V.; LIMA, J. M. G. M.; RODRIGUES, C. W. M. S.; BARBOSA, D. C. A. Erythrina velutina Willd. (leguminosae-papilionoideae) ocorrente em Caatinga e brejo de altitude de Pernambuco: biometria, embebição e germinação. Revista Árvore, Viçosa, v. 36, n. 2, p. 247 257, 2012.

SILVA, S. R.; ZAPPI, D. C.; TAYLOR, N.; MACHADO, M. (Org.). Plano de ação nacional para conservação das Cactáceas. Brasília: Instituto Chico Mendes de Conservação da Biodiversidade, 2011. 112 p.

VALADARES, J.; PAULA, R. C. de. Qualidade fisiológica de lotes de sementes de Poecilanthe parviflora Bentham (Fabaceae-Faboideae). Ceres, Viçosa, v. 55, n. 4, p. 273-279, 2015.

ZAPPI, D.; TAYLOR, N.; SANTOS, M. R.; LAROCCA, J. Cactaceae in lista de espécies da flora do Brasil. Rio de Janeiro: Jardim Botânico do Rio de Janeiro, 2015. Disponível em: <http://floradobrasil.jbrj.gov.br/reflora/ listaBrasil/>. Acesso em: 20 maio 2017. 
